\title{
COVID-19: NEGLIGÊNCIA GOVERNAMENTAL E PRECARIEDADE DO SISTEMA PÚBLICO DE SAÚDE
}

Gustavo Bristot Guimarães

Yago Marcelino Maciel

DOI: $h$ ttp://dx.doi.org/10.18616/intcov08

O poema "No meio do caminho", do modernista Drummond, revela de forma metafórica a existência de obstáculos no percurso humano. De maneira análoga, é possível perceber que a pandemia do Sars-CoV-2 tornou-se uma pedra no meio do caminho da sociedade moderna, haja vista que aprofunda a inexistência de um pleno bem-estar social. Assim, é preciso analisar como a negligência de parcela das autoridades e a precariedade do Sistema Único de Saúde (SUS) brasileiro contribuem para a intensificação desse grave problema contemporâneo.

Diante disso, é indubitável que a questão governamental e a sua ineficiente gestão estejam entre as causas do problema. Segundo o filósofo grego Aristóteles, a política deve ser utilizada de modo que, por meio da justiça, o equilíbrio seja alcançado na sociedade. Por outro lado, é possível perceber que, no Brasil, a displicência por parte do Poder Executivo rompe essa harmonia, haja vista que as orientações da Organização Mundial de Saúde (OMS) estão sendo ignoradas, colaborando para a desorientação da população e o consequente aumento do número de infectados. Tal atitude fundamenta-se em um discurso capitalista inconsequente, de modo que coloca a economia imediata acima da saúde da população, colocando em risco milhões de vidas e o mais impactante, causando dezenas de milhares de mortes em prol da saúde financeira em vez da humana, tornando aquele obstáculo apontado por Drummond ainda maior na realidade brasileira.

Outros sim, destaca-se como impulsionadora do problema a negligência histórica diante do SUS. De acordo com a Constituição Cidadã, todos os indivíduos da sociedade possuem o direito de receber acesso à saúde, sen- 
do dever do Estado oportunizá-la. Entretanto com o sucateamento da saúde intensificado pelo congelamento dos investimentos em serviços públicos pela "PEC do teto dos gastos", conhecida também como "PEC da morte", tal princípio de dever vem sendo descumprido, impedindo o acesso de milhares de brasileiros à garantia da dignidade de manter o seu equilíbrio fisco e mental em homeostase. Assim não apenas dezenas de milhares de pacientes estão perdendo sua vida para a covid-19, mas com a falta de Equipamentos de Proteção Individual (EPIs) e a falta de biossegurança os próprios profissionais da linha de frente da saúde estão perdendo o combate. No atual estágio, o Brasil é recordista mundial em morte de enfermeiros e médicos pela covid. Dessa forma, padece o sistema de saúde, usuários e profissionais, e a sociedade como um todo, estando novamente exposta a mais uma das barreiras estabelecidas pela falta de zelo constitucional, distanciando-se cada vez mais daquele equilíbrio aristotélico.

Portanto, diante do exposto, fica evidente que os entraves são a negligência de parcela das autoridades e o consequente descaso com o sistema de saúde brasileiro. Logo, com objetivo de garantir a saúde e o bem-estar de todos os cidadãos, o Ministério da Saúde deve absorver as orientações da OMS e garantir o cumprimento dessas medidas fundamentais diante de inédita pandemia. Por fim, é urgente uma maior coordenação dos setores públicos - especialmente a partir do governo federal - de modo que o sistema público de saúde tenha suporte físico e científico para prevenir e superar as novas ondas de infecção. Assim, toda a comunidade poderá receber os cuidados adequados e apropriados, afastando aquelas pedras do meio do caminho da sociedade contemporânea. 